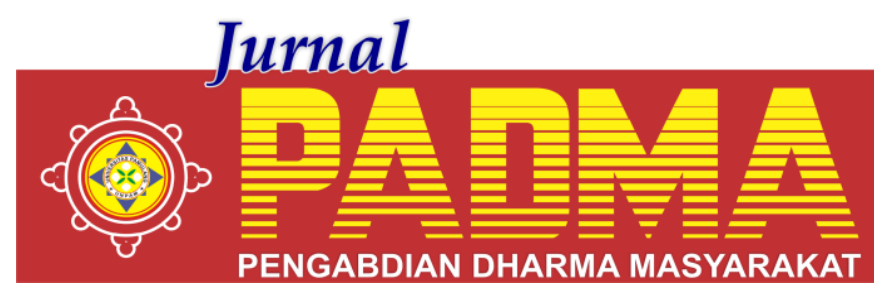

VOLUME 1, NOMOR 4, OKTOBER 2021

\title{
PEMANFAATAN WAKTU LUANG UNTUK MENGHADAPI MASA PANDEMI COVID-19 DENGAN BELAJAR HIDUP SEHAT BERSAMA ANAK RUMAH YATIM DHUAFA RAYDHA AULIA
}

\author{
${ }^{1 *}$ Desi Ayu Ningrum, ${ }^{2}$ Dewi Laras Sari, ${ }^{3}$ Muhammad Abduh, \\ ${ }^{4}$ Ramadhan Zidane, ${ }^{5}$ Rara Syahfitri \\ Universitas Pamulang, Tangerang Selatan, Banten, Indonesia \\ *ndesi0562@gmail.com
}

\begin{abstract}
Abstrak
Tujuan Pengabdian Kepada Masyarakat (PKM) Mahasiswa ini adalah untuk memberikan pengetahuan dan pemahaman kepada anak-anak Rumah Yatim Dhuafa Raydha Aulia yang bertempat di Jl. Kesadaran II, Pd. Petir, Kec. Bojongsari, Depok, Tangerang Selatan. Adapun metode kegiatan ini adalah mendatangi rumah yatim tersebut memberikan pengetahuan dan diskusi mengenai pentingnya belajar hidup sehat di massa pandemi covid-19 agar terhindar dari virus dan kuman yang membahayakan kesehatan. Serta memberikan pemahaman bagaimana menjaga kebersihan, pola makan dan memakai masker. Hasil dari kegiatan tersebut adalah para anak-anak menjadi lebih memahami pentingnya untuk menjaga kesehatan dengan hidup sehat dan mencegah dari penularan covid-19. Untuk kedepannya anakanak Rumah yatim Dhuafa Aulia akan lebih menjaga kebersihan dan menerapkan pola hidup sehat.
\end{abstract}

Kata Kunci: Kesehatan, Covid-19

Abstract
The purpose of this Student Community Service (PKM) is to provide knowledge and understanding to the children of the Dhuafa Raydha Aulia Orphanage which is located on Jl. Consciousness II, Pd. Lightning, District. Bojongsari, Depok, South Tangerang. The method of this activity is to visit the orphanage to provide knowledge and discussion about the importance of learning to live healthy during the COVID-19 pandemic to avoid viruses and germs that endanger health. As well as providing an understanding of how to maintain cleanliness, eating patterns and wearing masks. The result of this activity is that the children have a better understanding of the importance of maintaining health by living healthy and preventing the spread of COVID-19. In the future, the children of the Dhuafa Aulia orphanage will be more hygienic and implement a healthy and healthy lifestyle.

Keywords: Health, Covid-19

\section{PENDAHULUAN}

Panti Asuhan merupakan lembaga yang bergerak di bidang sosial untuk membantu anak-anak yang sudah tidak memiliki orang tua. Di dalam Kamus Besar Bahasa Indonesia (2001), panti asuhan merupakan sebuah tempat untuk yang bergerak di bidang sosial untuk membantu anak-anak yang sudah tidak memiliki orang tua. Di dalam Kamus Besar Bahasa Indonesia (2001), panti asuhan merupakan sebuah tempat untuk merawat dan memelihara anak-anak yatim atau yatim piatu. Pengertian yatim adalah tidak memiliki seorang ayah, sedangkan yatim piatu adalah tidak memiliki seorang ayah dan ibu. Namun, tidak hanya untuk anak yatim maupun yatim piatu, panti asuhan juga terbuka untuk anak-anak selain mereka, seperti anak terlantar.

Anak- anak yang kurang beruntung seperti yang dipaparkan di atas juga dapat bertempat tinggal di panti asuhan. Jumlah panti asuhan di seluruh Indonesia diperkirakan antara 5.000-8.000 yang mengasuh sampai setengah juta anak. Pemerintah Indonesia hanya memiliki dan menyelenggarakan sedikit dari panti asuhan tersebut, lebih dari 99\% panti asuhan diselenggarakan oleh masyarakat, seperti anak yatim, anak piatu, anak yatim piatu, anak terlantar dan anak yang tidak mampu. Bertempat tinggal dan hidup di panti asuhan bukanlah hal yang mudah bagi anak, khususnya bagi remaja. Karena mereka tidak mendapatkan hangatnya kasih sayang 
orang tua kandung. Santi (2011) dalam makalahnya menjelaskan bahwa dalam penelitian yang telah dilakukan oleh lembaga Save The Children, terdapat kasuskasus eksploitasi terhadap anak di dalam panti asuhan, sehingga fungsi panti asuhan sebagai lembaga asuhan alternatif tidak dapat melindungi anak yang berada di luar asuhan keluarga secara aman. Sebaliknya anak-anak tumbuh dalam lingkungan yang tidak kondusif, tidak protektif yang akan mengganggu terhadap tumbuh kembang anak.

Rumah Yatim Dhuafa Raydha Aulia merupakan salah satu panti asuhan yang mempunyai latar belakang keagamaan, sehingga setiap anak yang tinggal di panti diberikan bekal agama setiap harinya. Hal ini diupayakan untuk memperluas pengetahuan agama dan mempertinggi tingkat religiusitas anak. Sebagian remaja panti melakukan aktivitas keberagamaan karena remaja panti tidak memiliki pilihan lain, sehingga harus menjalankannya. Remaja panti harus melakukan berbagai macam kegiatan yang berhubungan dengan keagamaan dan kegiatan lainnya dari pagi sampai malam karena hal tersebut merupakan suatu kewajiban yang mau tidak mau harus dipatuhi dan dilaksanakan.

\section{METODE}

Pelaksanaan kegiatan pengabdian berlangsung pada tanggal 6 Maret 2021, dengan dihadiri 15 (Lima Belas) di Rumah Yatim Dhuafa Raydha Aulia yang beralamat di Jl. Kesadaran II, Pd. Petir, Kec. Bojongsari, Depok, Tangerang Selatan. Banten. Ada beberapa metode pendekatan yang digunakan dalam pelaksanaan program, meliputi sebagai berikut:

1. Sosalisasi

Program pengabdian kepada masyarakat dilaksanakan dalam bentuk sosialisasi kepada anak-anak Rumah Yatim Dhuafa Raydha Aulia. Sosialisasi tersebut berupa pemaparan materi kepada anak-anak Rumah Yatim Dhuafa Raydha Aulia

2. Praktek

Setelah materi selesai dipaparkan, dilanjutkan dengan praktek berupa cara mencuvitangan serta memakai masker yang baik dan benar. Praktek ini dilakukan agar peserta lebih memahami materi yang telah disampaikan.

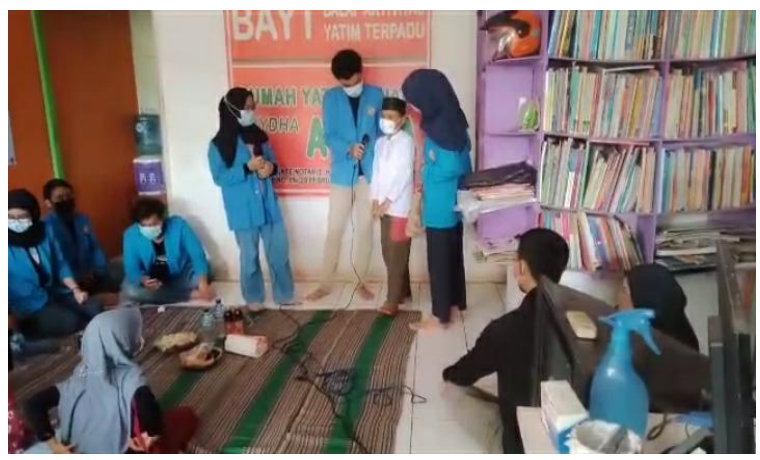

Gambar 1. Penyampaian Materi

\section{HASIL DAN PEMBAHASAN}

\section{Covid-19}

Covid -19 merupakan nama penyakit yang disebabkan oleh virus corona, yang merupakan singkatan dari Corona Virus Disease-2019. Penyakit yang menyerang saluran pernafasan.

a. Gejala penularan covid-19
1) Demam tinggi
2) Batuk dan Flu
3) Sesak nafas
4) Nyeri tenggorokan
5) Nyeri Otot

b. Menanggulangi dan mencegah covid-19

1) Rajin mencuci tangan

2) Kurangi berinteraksi dengan orang lain

3) Gaya hidup sehat

4) Menjaga jarak

5) Hindari kerumunan

6) Hindari menyentuh mata, hidung, dan mulut

7) Hindari bepergian ke daerah yang terjangkit

8) Etika batuk dan bersin, hindari meludah ditempat umum

9) Olah daging mentah dengan hatihati

10) Hindari memakan daging hewan yang sakit

11) Segera berobat dan gunakan masker bila sedang sakit

12) Selalu berdoa kepada tuhan yang maha melindungi

\section{Belajar Dimasa Pandemi}

Berikut ini adalah Strategi belajar dan menerapkan hidup sehat dirumah: 
a. Menjaga kebersihan dengan menjaga pola hidup sehat :

1) Mengkonsumsi makanan sehat dan bergizi.

2) Minuman yang sehat.

3) Gizi seimbang

4) Olahraga

5) Istirahat yang cukup

b. Belajar efektif dirumah

1) Tetap mengoptimalkan manajemen waktu agar tetap teratur .

2) Mempersiapkan peralatan belajar online dengan baik.

3) Belajar serius dan fokus.

4) Menjaga komunikasi dengan pengajar dan teman-teman dikelas.

Pelaksanaan Pengabdian Kepada Masyarakat (PKM) yang dilakukan oleh mahasiswa Universitas Pamulang kepada anak-anak Rumah Yatim Dhuafa Raydha Aulia, Sosialisasi ini merupakan bentuk sosialisasi dimana pentingnya menjaga kebersihan dan menerapkan pola hidup sehat dimasa pandemic Covid-19.

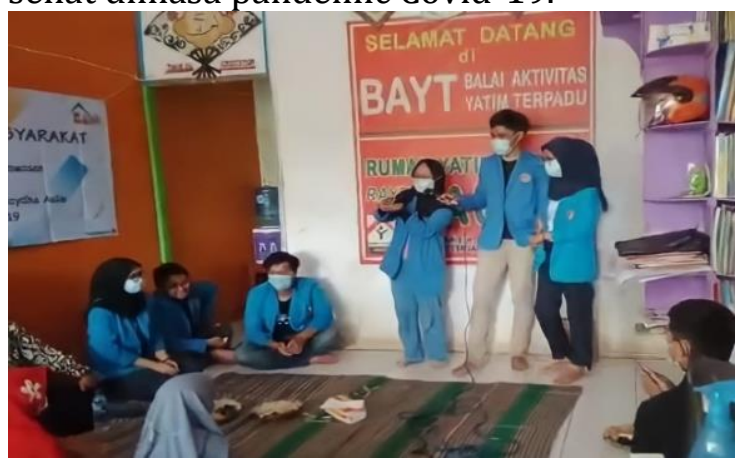

Gambar 2. Penyampaian Materi

\section{PENUTUP}

\section{KESIMPULAN}

Kegiatan pengapdian masyarakat ini dapat membantu dan memotivasi anak agar terus belajar hidup sehat dengan metode yang lebih senang dan ringan. Sehingga kedepannya bagi para pengajar ataupun pengasuh dari pihak sekolah maupun yayasan Rumah Yatim Dhuafa Raydha Aulia dapat menerapkan kegiatan hidup sehat.

\section{SARAN}

Semoga program ini dapat membantu pengurus yayasan serta anak asuh agar lebih memperhatikan Pembentukan Perilaku hidup sehat di masa pandemic covid-19 ini.

\section{DAFTAR PUSTAKA}

Depdiknas. (2001). Kamus Besar Bahasa Indonesia. Jakarta: Balai Pustaka.

Isfandiari, M.A. (2020). Corona Virus (Covid19) Hasil Kajian. Dosen FKM Unair

Lewenussa, R., \& Rawi, R. D. P. (2020). Discriminant Study with Classification of Underdeveloped and Developing City Districts in West Papua Province. Ekuilibrium: Jurnal Ilmiah Bidang Ilmu Ekonomi, 15(2), 103-117.

Nurjaya, N., et al. (2021). Pengaruh Kompetensi Sumber Daya Manusia Dan Kemampuan Pemanfaatan Teknologi Terhadap Kinerja Aparatur Desa Pada Kantor Kepala Desa Di Kabupaten Gunungkidul, Yogyakarta. JENIUS (Jurnal Ilmiah Manajemen Sumber Daya Manusia), 4(3), 332-346.

Sunarsi, D. (2019). Penerapan MSDM Strategis Dalam Upaya Meningkatkan Kemampuan Organisasi dalam menyongsong Revolusi 4.0. Jurnal Ilmiah MEA (Manajemen, Ekonomi, \& Akuntansi), 3(1), 221-233.

Suryani, Y. (n.d.). Implementasi Gaya Hidup Kerohanian Mahasiswa Iakn Toraja Dalam Menyikapi Pencegahan Covid 19.

Telaumbanua, D. (2020). Urgensi Pembentukan Aturan Terkait Pencegahan Covid-19 di Indonesia. QALAMUNA: Jurnal Pendidikan, Sosial, Dan Agama, 12 (01) ,59-70. 